\title{
PENGEMBANGAN MEDIA KOMIK DIGITAL AKUNTANSI PADA MATERI MENYUSUN LAPORAN REKONSILIASI BANK UNTUK SISWA SMK
}

\section{THE DEVELOPMENT OF ACCOUNTING DIGITAL COMIC MEDIA IN THE MATERIAL OF WRITING BANK RECONCILIATION REPORT FOR STUDENTS OF VOCATIONAL SECONDARY SCHOOL}

\author{
Yuliana Faridatul Hidayah, Siswandari, Sudiyanto \\ Universitas Sebelas Maret Surakarta \\ Jalan Ir. Sutami No. 36A, Jebres, Surakarta, Jawa Tengah \\ e-mail: you.lianafh91@gmail.com, namaku_ndari@yahoo.co.uk \\ soeddie.fkipuns@gmail.com
}

Naskah diterima tanggal: 12-07-2017, disetujui tanggal: 28-08-2017

\begin{abstract}
This study aimed to develop accounting digital comic media in the material of writing bank reconciliation reports for XI grade of students of vocational secondary school that is feasible to be used in the learning process. This study was a research and development refered to Borg and Gall's model, with three stages of research namely preliminary study stage, product design development and product validation. The subject of the research were students XI grade of SMK Muhammadiyah 3 Gemolong. Data collection techniques included observation, interviews, questionnaires, and validation of expert teams. The results revealed that the process of accounting learning in SMK Muhammadiyah 3 Gemolong had not used technology-based media optimally. The product design of accounting digital comic media was validated by expert teams of media, material, linguist, and practitioners (accounting teachers). Based on the validation of expert team, the accounting digital comic media included into the very well category and comformed with media feasibility criteria. To conclude, this accounting digital comic media can be tried out in the next stage and used in accounting learning process at vocational secondary school.
\end{abstract}

Keywords: learning media, digital comic, accounting, vocational secondary school

\begin{abstract}
Abstrak: Penelitian ini bertujuan untuk mengembangkan media komik digital akuntansi dengan materi menyusun laporan rekonsiliasi bank untuk siswa kelas XI SMK yang layak dipergunakan dalam proses pembelajaran. Penelitian ini merupakan penelitian dan pengembangan yang mengacu pada model Borg dan Gall dengan tiga tahapan penelitian yakni tahap studi pendahuluan, pengembangan desain produk dan validasi produk. Subjek penelitian ini adalah siswa kelas XI SMK Muhammadiyah 3 Gemolong. Teknik pengumpulan data yang digunakan meliputi observasi, wawancara, angket, dan validasi tim ahli. Berdasarkan hasil penelitian yang telah dilakukan sebelumnya, proses pembelajaran akuntansi di SMK Muhammadiyah 3 belum memanfaatkan penggunaan media berbasis teknologi secara optimal. Pengembangan desain produk (prototipe) media komik digital akuntansi telah divalidasi oleh tim ahli dengan hasil penilaian dari ahli media, ahli materi, ahli bahasa, dan praktisi. Berdasarkan validasi oleh tim ahli, media pembelajaran komik digital akuntansi ini termasuk dalam kategori sangat baik dan sesuai dengan kriteria kelayakan media. Dengan demikian, media komik digital akuntansi ini dapat diujicobakan pada tahapan selanjutnya dan digunakan dalam proses pembelajaran akuntansi di SMK.
\end{abstract}

Kata kunci: media pembelajaran, komik digital, akuntansi, SMK 


\section{PENDAHULUAN}

Pembelajaran merupakan proses interaksi antara peserta didik dan lingkungan belajarnya. Lingkungan belajar mendukung keberhasilan suatu proses pembelajaran, sehingga lingkungan belajar harus dikelola dan dirancang dengan baik dalam mengembangkan berbagai pengetahuan, kemampuan, keterampilan, dan sikap peserta didik. Pembelajaran efektif berfokus pada kegiatan pembelajaran yang mengarahkan pada pencapaian tujuan pembelajaran. Hal ini sejalan dengan yang dikemukakan oleh Zheng, Yang, Cheng, \& Huang, (2013) yang menyatakan bahwa aktivitas pembelajaran efektif merupakan proses dalam menyelesaikan tugas belajar dan mencapai tujuan belajar dalam waktu yang diharapkan, sehingga dapat dikatakan bahwa pembelajaran efektif berorientasi pada keberhasilan pencapaian tujuan pembelajaran. Komponen-komponen yang diperlukan dalam mencapai keberhasilan proses pembelajaran, diantaranya adanya tujuan pembelajaran, bahan pelajaran, media pembelajaran, strategi pembelajaran, dan evaluasi pembelajaran (Rusman, Kurniawan, \& Riyana, 2012). Komponen tersebut memiliki keterkaitan antara satu dengan yang lain, sehingga perlu mengintegrasikannya demi tercapainya keberhasilan pembelajaran.

Media pembelajaran merupakan sarana atau alat yang digunakan untuk menyampaikan berbagai pesan/informasi pembelajaran kepada peserta didik. Smaldino, Lowther, \& Russell (2008) mengungkapkan bahwa media pembelajaran berperan sebagai sarana komunikasi dalam proses belajar-mengajar yang bertujuan untuk mencapai proses dan hasil pembelajaran secara efektif dan efisien. Pada dasarnya, penggunaan media dalam pembelajaran bertujuan untuk membantu dalam mencapai tujuan pembelajaran. Pemilihan media yang akan digunakan dalam proses pembelajaran perlu mempertimbangkan beberapa aspek, diantaranya kemampuan yang diharapkan dari peserta didik, karakteristik dan gaya belajar peserta didik, lingkungan belajar, dan lingkungan pengembangan (Anitah, 2010). Karakteristik dan gaya belajar siswa yang berbeda perlu dipertimbangkan dalam menentukan media yang dapat digunakan dalam memenuhi kebutuhan belajar siswa. Oleh karena itu, penggunaan multimedia dalam pembelajaran menjadi salah satu alternatif dalam memenuhi kebutuhan belajar siswa dengan karakteristik yang berbeda. Sebagaimana yang diungkapkan oleh Newby, Stepich, Lehman, \& Russell (2000) bahwa multimedia merupakan kombinasi antara beberapa jenis media yang berbeda. Multimedia merupakan integrasi dari beberapa jenis media dan teknologi yang berbeda untuk meningkatkan proses pembelajaran.

Pendidikan kejuruan merupakan jalur pendidikan formal yang bertujuan untuk menghasilkan lulusan yang siap kerja dan mampu memenuhi kebutuhan dunia kerja. Oleh karena itu, lulusan SMK perlu dibekali dengan berbagai pengetahuan dan keterampilan yang andal untuk memasuki dunia kerja yang sesuai dengan bidang keahliannya.

Akuntansi merupakan salah satu bidang keahlian yang terdapat dalam jenjang pendidikan SMK yang bertujuan untuk menghasilkan lulusan yang kompeten dan profesional di bidang akuntansi, sehingga untuk mewujudkan hal tersebut perlu ada peningkatan kualitas pembelajaran akuntansi di sekolah kejuruan. Namun, pada studi pendahuluan yang telah dilakukan di SMK Muhammadiyah 3 Gemolong diketahui bahwa penggunaan media pembelajaran belum dimanfaatkan secara optimal. Hal ini disebabkan masih banyaknya guru yang mengalami kesulitan dalam menyusun dan mengembangkan media pembelajaran akuntansi. Selain itu, penggunaan media pembelajaran berbasis teknologi hanya terbatas pada materi tertentu. Proses pembelajaran akuntansi di sekolah belum dapat memaksimalkan keaktifan dan keterlibatan siswa dalam mengikuti proses pembelajaran. Oleh karena itu, banyak siswa yang mengalami kesulitan dalam memahami materi akuntansi yang diajarkan, dan menganggap akuntansi merupakan pelajaran yang 
sulit untuk dipahami, sehingga mempengaruhi hasil belajar siswa.

Komik merupakan salah satu jenis bacaan yang digemari siswa. Berdasarkan hasil studi pendahuluan yang dilakukan penulis, diperoleh data sebesar $86,36 \%$ siswa senang membaca komik atau cerita bergambar. Hal ini sejalan dengan hasil penelitian yang dilakukan oleh Waskithasari dan Setiasih (2008) bahwa bacaan non-akademis yang diminati remaja, yakni novel $(24,5 \%)$, komik $(24,5 \%)$, majalah $(15,1 \%)$, cerpen $(8,5 \%)$, buku ilmiah $(7,5 \%)$, buku psikologi $(5,7 \%)$, buku agama $(4,7 \%)$, buku kisah nyata $(4,7 \%)$, buku humor ilmiah $(2,8 \%)$, buku biografi $(1,9 \%)$. Keunggulan komik yang sangat digemari siswa dapat dimanfaatkan dalam proses pembelajaran. Penggunaan komik dalam proses pembelajaran memberikan kontribusi tinggi terhadap daya ingat dan memori jangka panjang siswa (Mcloud dalam Negerete, 2013). Komik merupakan bentuk seni populer di kalangan anak-anak dan merupakan media potensial untuk kegiatan pendidikan dan komunikasi (Tatalovic, 2009).

Perkembangan teknologi dapat dikombinasikan dengan keunggulan komik untuk menghasilkan media pembelajaran yang bermanfaat bagi siswa. Salah satunya dengan media komik digital. Komik digital merupakan komik sederhana yang disajikan dalam media elektronik tertentu (Lamb \& Johnson, 2009). Komik digital juga dapat didefinisikan sebagai komik yang diterbitkan/disajikan dalam website, webcomics, online comics, atau internet comics (Yunus, dkk., 2010). Dengan demikian, dapat dikatakan bahwa komik digital merupakan suatu bentuk cerita bergambar dengan tokoh karakter tertentu yang menyajikan informasi/ pesan melalui media elektronik. Penyajian komik yang berbasis elektronik memungkinkan guru dapat membuat cerita komik lebih menarik dengan menambahkan unsur animasi dan suara dalam penyajiannya.

Penggunaan komik digital dalam proses pembelajaran akan memberikan tanggapan positif dari siswa. Siswa antusias dalam mengikuti proses pembelajaran dengan menggunakan komik digital, suasana belajar yang menyenangkan dan informasi yang disajikan lebih mudah dipahami karena penyajiannya yang menarik, dan memadukan berbagai unsur gambar, narasi dan animasi. Hal ini sejalan dengan yang diungkapkan oleh Comer (2015) bahwa mengombinasikan kata, gambar, gesture, dan audio benar-benar memberikan pengalaman menarik bagi siswa. Selanjutnya, Mayer (dalam Wankel \& Blessinger, 2013) mengungkapkan bahwa seseorang dapat belajar lebih baik dengan mengombinasikan gambar dan tulisan.

Berdasarkan penelitian yang dilakukan sebelumnya oleh Yang \& Wu (2011) penggunaan komik digital dapat meningkatkan pemahaman siswa mengenai isi pelajaran, keinginan siswa dalam mengeksplorasi dan meningkatkan kemampuan berpikir kritis. Selain itu, Azman, Zaibon, \& Shiratuddin (2016) mengungkapkan bahwa penggunaan digital comic/digital storytelling dapat mengembangkan kreativitas, inovasi, motivasi, aktivitas belajar, dan pengalaman belajar yang bernilai bagi peserta didik. Dengan demikian, dapat dikatakan bahwa penggunaan media komik digital dapat meningkatkan ketertarikan dan keterlibatan siswa dalam mengikuti proses pembelajaran dan membuat aktivitas belajar menjadi lebih menyenangkan.

Oleh karena itu, dalam penelitian ini akan dikembangkan media pembelajaran komik digital yang dapat digunakan dalam proses pembelajaran akuntansi di SMK Muhammadiyah 3 Gemolong. Adapun rumusan masalah dalam penelitian ini ialah, bagaimana mengembangkan media pembelajaran komik digital akuntansi yang layak untuk dapat digunakan dalam proses pembelajaran. Tujuan dari penelitian ini yaitu mengembangkan media komik digital akuntansi yang layak dipergunakan untuk siswa kelas XI SMK Muhammadiyah 3 Gemolong.

\section{METODE}

Jenis penelitian ini merupakan penelitian dan pengembangan, yakni suatu proses pengem- 
bangan perangkat atau produk tertentu yang dilakukan melalui serangkaian riset yang menggunakan berbagai metode dalam suatu siklus yang melewati berbagai tahapan. Tahapan tersebut adalah: 1) mempelajari berbagai temuan riset yang berkaitan dengan perangkat yang akan dijadikan produk yang dikembangkan, 2) mengembangkan bentuk awal perangkat berdasarkan temuan-temuan riset itu, 3) melakukan serangkaian pengujian lapangan (tiga kali eksperimentasi atau lebih) pada tempat digunakannya produk itu, dan 4) merevisi produk untuk memperbaiki berbagai kelemahan dan kekeliruan yang ditemukan dari hasil setiap pengujian lapangan (Ali \& Asrori, 2014).

Penelitian ini dilaksanakan pada November 2016 sampai dengan April 2017, dan bertujuan untuk mengembangkan media pembelajaran komik digital akuntansi pada materi menyusun laporan rekonsiliasi bank yang akan digunakan siswa SMK Muhammadiyah 3 Gemolong. Pemilihan lokasi penelitian didasarkan pada beberapa pertimbangan, diantaranya: 1) Kesesuaian dengan permasalahan yang diteliti dan tersedianya data yang dibutuhkan; 2) Sesuai dengan analisis kebutuhan yang berkenaan dengan media pembelajaran; dan 3) Tersedianya sarana dan prasarana yang dapat menunjang penggunaan media pembelajaran komik digital akuntansi.

Subjek penelitian ini merupakan siswa kelas XI SMK Muhammadiyah 3 Gemolong. Desain alur penelitian yang akan digunakan dalam penelitian ini mengacu pada model pengembangan Borg dan Gall yang dimodifikasi oleh Sugiyono (2015). Penelitian ini diawali dengan studi pendahuluan untuk menggali potensi dan mengidentifikasi masalah yang terjadi dalam proses pembelajaran akuntansi di SMK. Studi pendahuluan dilakukan dengan dua cara yakni dengan melakukan studi literatur untuk memperoleh berbagai teori dan informasi yang mendukung pentingnya peranan media dalam proses pembelajaran. Selain itu, untuk memperoleh data faktual yang terjadi di sekolah dilakukan observasi, wawancara, dan analisis kebutuhan siswa dan guru mengenai penggunaan media pembelajaran akuntansi.

Berbagai data dan informasi yang diperoleh dijadikan dasar pertimbangan dalam mengembangkan media pembelajaran komik digital akuntansi di SMK. Desain media pembelajaran (prototipe) komik digital akuntansi yang telah dikembangkan selanjutnya akan divalidasi oleh tim ahli, yang meliputi ahli media, materi, bahasa, dan praktisis untuk menilai kelayakan media yang dikembangkan. Setelah media komik digital telah dinyatakan layak oleh tim ahli, dilakukan uji coba terbatas terhadap 10 siswa kelas XI SMK untuk mengetahui respon mereka terhadap penggunaan media komik digital. Desain penelitian dapat dilihat pada Gambar 1.

Teknik pengumpulan data yang digunakan dalam penelitian ini, meliputi kuesioner/angket, observasi, wawancara dan validasi tim ahli (expert judgement). Observasi dan wawancara dilakukan untuk memperoleh informasi secara langsung mengenai proses pembelajaran akuntansi di sekolah. Angket digunakan untuk melakukan analisis kebutuhan guru dan siswa, sebagai dasar pertimbangan dalam mengembangkan media pembelajaran yang dibutuhkan di sekolah. Lembar validasi digunakan untuk menilai kelayakan media yang telah dikembangkan yang akan dilakukan oleh ahli media, ahli materi, ahli bahasa, dan praktisi, yakni guru akuntansi di sekolah. Berbagai saran dan masukan dari tim ahli (expert judgement) akan digunakan sebagai dasar dalam memperbaiki produk media yang dihasilkan sehingga memperoleh media komik digital akuntansi yang layak untuk digunakan dalam pembelajaran. Teknik analisis data yang digunakan yaitu analisis deskriptif kualitatif untuk observasi dan wawancara, dan deskriptif kuantitatif untuk angket dan validasi media oleh tim ahli. 


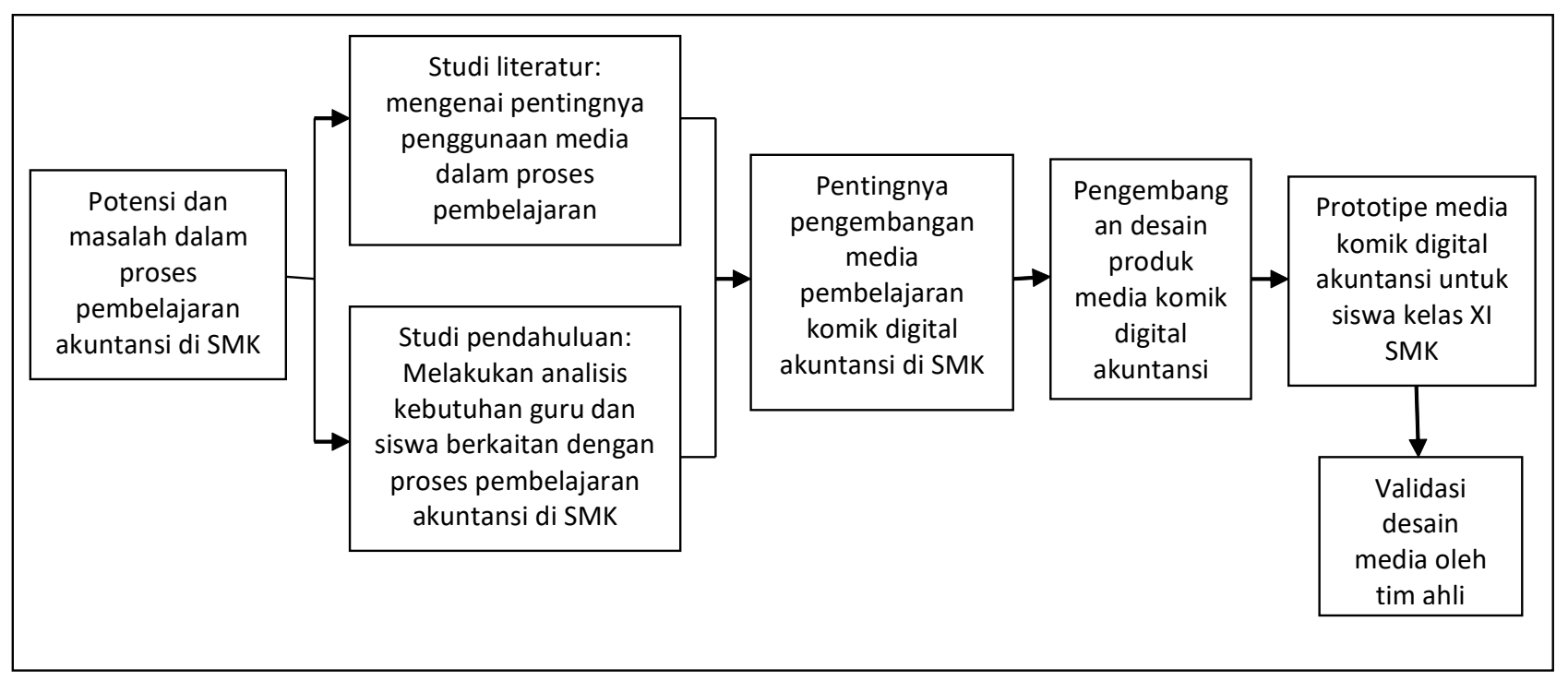

Gambar 1 Desain Penelitian

\section{HASIL DAN PEMBAHASAN}

\section{Studi Pendahuluan}

Studi pendahuluan dilakukan untuk memperoleh informasi dan data mengenai proses pembelajaran akuntansi di SMK Muhammadiyah 3 Gemolong. Berdasarkan hasil observasi dan wawancara yang telah dilakukan diperoleh informasi bahwa proses pembelajaran akuntansi di sekolah telah berjalan dengan baik. Namun, masih terdapat beberapa kekurangan dan kendala dalam menunjang proses pembelajaran, seperti yang diungkapkan oleh siswa bahwa penggunaan buku paket sangat minim. Selain itu, penggunaan media dalam proses pem- belajaran juga jarang dilakukan. Kurangnya penggunaan media dalam pembelajaran mengakibatkan banyak siswa yang merasa jenuh dan bosan dalam mengikuti pelajaran akuntansi. Selain itu, beberapa siswa mengungkapkan bahwa materi mengelola dana kas bank, khususnya menyusun laporan rekonsiliasi merupakan materi akuntansi yang dirasa sangat sulit untuk dipahami siswa. Hal ini sejalan dengan hasil analisis kebutuhan siswa melalui angket yang telah diberikan. Berdasarkan angket analisis kebutuhan siswa diperoleh data seperti Gambar 2 .

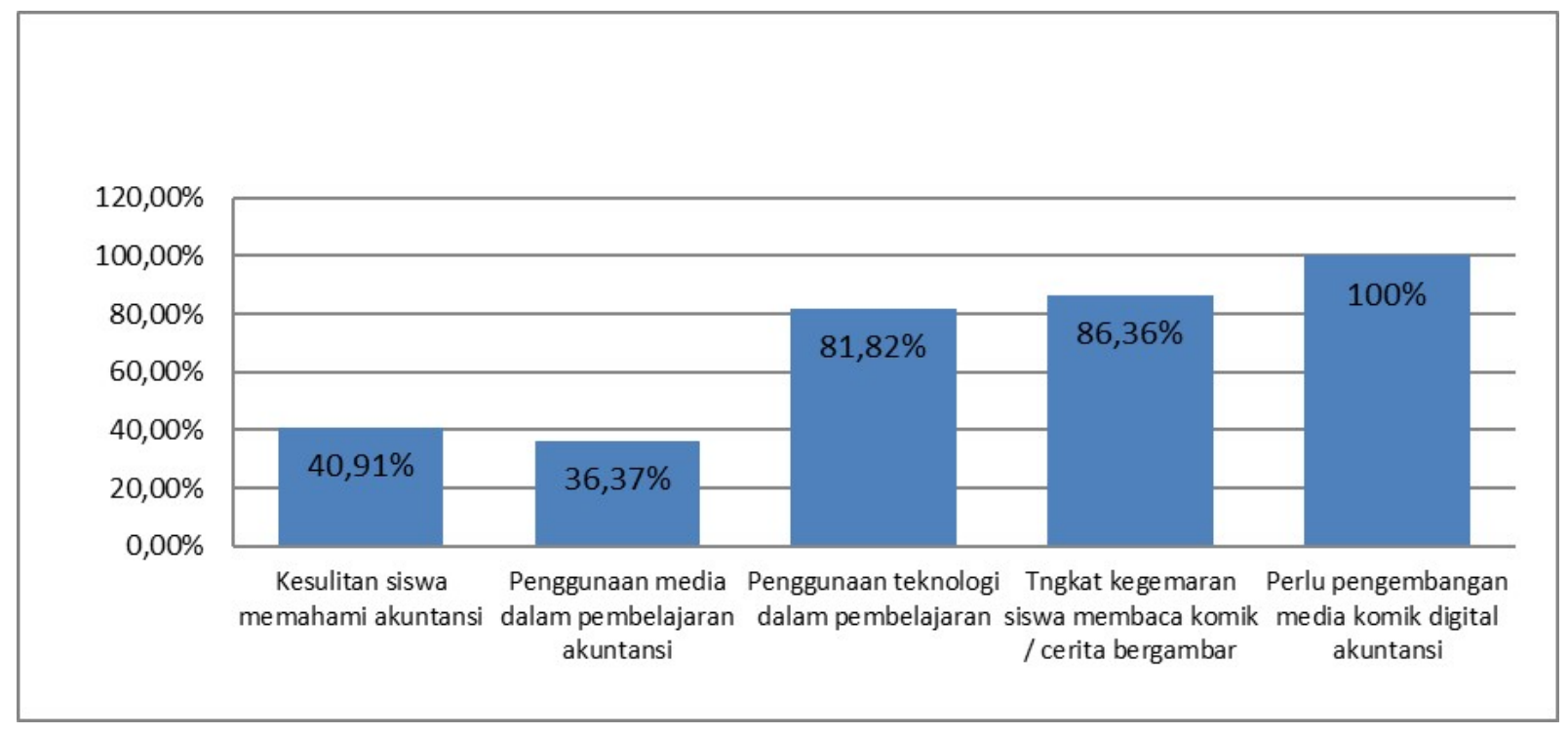

Gambar 2 Hasil Analisis Kebutuhan Siswa 
Berdasarkan data tersebut diketahui sebanyak 40,91\% siswa mengalami kesulitan dalam memahami materi akuntansi yang disampaikan guru. Penggunaan media dalam pembelajaran akuntansi di sekolah hanya sebanyak 36,37\%, sedangkan penggunaan teknologi dalam pembelajaran akuntansi sebanyak $81,82 \%$. Penggunaan teknologi dalam proses pembelajaran akuntansi di sekolah hanya terbatas pada materi-materi tertentu, seperti MYOB dan spreadsheet. Selanjutnya sebanyak $86,36 \%$ siswa gemar membaca komik atau cerita bergambar. Kondisi di atas dapat dimanfaatkan guru dalam mengembangkan media pembelajaran akuntansi yang lebih menarik dengan pemanfaatan komik. Sebanyak 100\% siswa merasa perlu dan setuju untuk mengembangkan media komik digital akuntansi.

Penggunaan media pembelajaran di sekolah diakui guru belum dilakukan secara maksimal karena adanya keterbatasan sarana-prasarana yang dimiliki. Selain itu, masih banyaknya guru yang merasa kesulitan dalam menyusun dan mengembangkan media pembelajaran berbasis teknologi.

Penggunaan media pembelajaran berbasis teknologi dalam proses pembelajaran hanya terbatas pada beberapa materi tertentu dan hanya terbatas pada media visual berupa powerpoint yang menampilkan materi dalam bentuk personal presentation. Berdasarkan angket analisis kebutuhan guru diperoleh data seperti pada Gambar 3.

Berdasarkan Gambar 3 diperoleh informasi bahwa tingkat penggunaan media pembelajaran dan pemanfaatan di kelas dalam proses pembelajaran akuntansi adalah $80 \%$. Selanjutnya, diperoleh data bahwa hanya $40 \%$ guru yang telah mengembangkan media pembelajaran akuntansi. Sebanyak $80 \%$ guru mengungkapkan adanya kesulitan dalam mengembangkan dan menyusun media pembelajaran akuntansi meskipun mereka menyadari pentingnya peranan media dalam proses pembelajaran dan keberhasilan pembelajaran. Oleh karena itu, 100\% guru setuju dan merasa perlu untuk dikembangkan media komik digital yang dapat digunakan dalam pembelajaran akuntansi di sekolah.

\section{Desain Produk}

Hasil studi pendahuluan yang diperoleh sebelumnya menjadi salah satu pedoman dalam penyusunan draf produk media pembelajaran komik digital akuntansi. Dalam menyusun desain produk awal media terdapat beberapa hal yang harus dilakukan, yakni menetapkan standar kompetensi dan kompetensi dasar yang akan dikembangkan dalam media komik digital akuntansi. Dalam penelitian ini kompetensi dasar

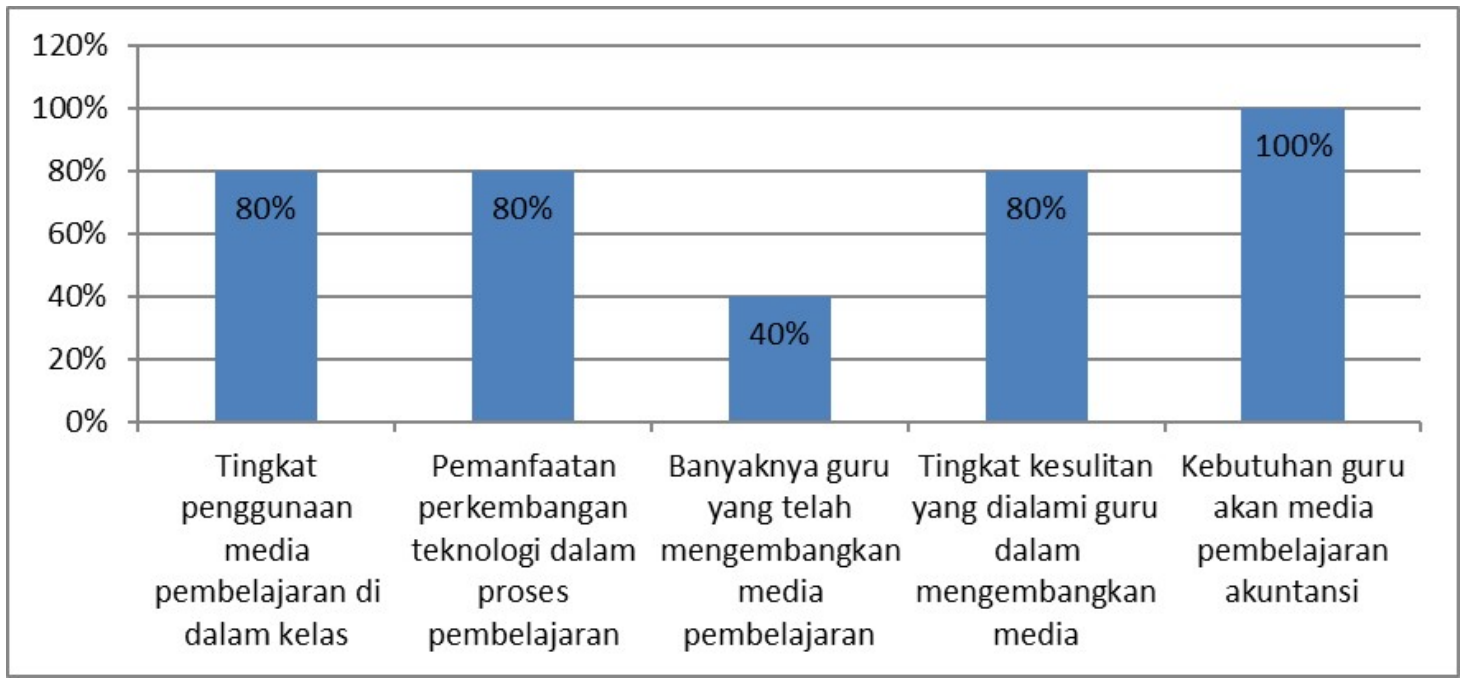

Gambar 3 Hasil Analisis Kebutuhan Guru 
yang dipilih ialah menyusun laporan rekonsiliasi bank yang didasarkan pada hasil analisis kebutuhan siswa yang telah dilakukan sebelumnya.

Konten dan isi media komik digital akan membahas materi mengelola administrasi kas bank. Materi tersebut akan disajikan dalam video animasi yang terdiri dari tiga bagian. Pertama, bagian pendahuluan (introduction) yang akan menyajikan informasi awal mengenai konsep pengelolaan kas perusahaan. Kedua, bagian komik digital (digital comic) akan menyajikan proses menyusun laporan rekonsiliasi yang disajikan dalam sebuah cerita komik. Ketiga, bagian latihan (drill and practice) akan menampilkan pertanyaan mengenai proses penyusunan laporan rekonsiliasi untuk mengetahui pemahaman siswa mengenai materi yang disampaikan melalui media komik digital.

Konten dan isi media yang telah ditentukan sebelumnya menjadi pedoman bagi peneliti dalam membuat flowchart dan menyusun storyboard media pembelajaran komik digital akuntansi. Beberapa aplikasi yang dipergunakan dalam mengembangkan media komik digital akuntansi, meliputi:

1. CorelDraw $X 5$ digunakan untuk melakukan editing terhadap gambar-gambar tokoh dan karakter yang akan dimasukkan dalam komik digital akuntansi yang akan dikembangkan.

2. Sparkol Videoscribe, yakni software yang digunakan dalam membuat desain animasi dengan latar putih dan mudah untuk digunakan. Software ini digunakan untuk menggabungkan beberapa gambar yang telah di-edit sebelumnya pada aplikasi CorelDraw, sehingga menghasilkan suatu alur cerita komik dalam bentuk video animasi.

3. Videopad, digunakan untuk melakukan editing terhadap video yang telah dihasilkan dari aplikasi sparkol videoscribe dan memasukkan suara dalam percakapan komik digital akuntansi.
4. Articulate Storyline, digunakan untuk membuat tampilan menu media pembelajaran komik digital akuntansi, agar siswa dapat memilih materi yang ingin dipelajari dan mempermudah penggunaannya.

Berikut merupakan desain komik digital akuntansi yang dihasilkan:

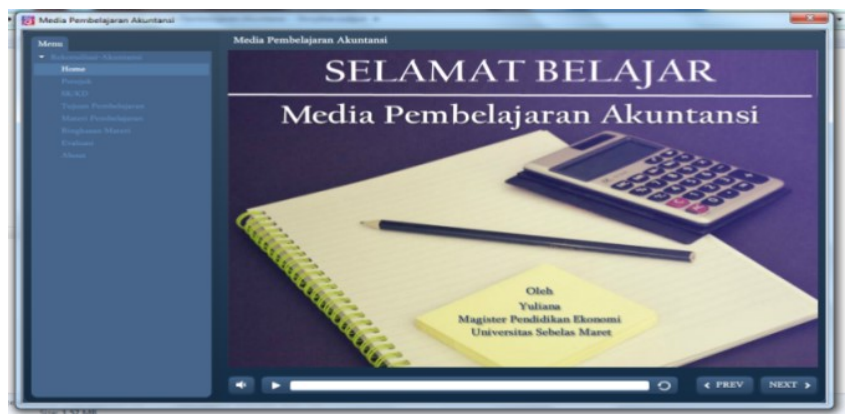

Gambar 4 Halaman Pembuka Media Komik Digital Akuntansi

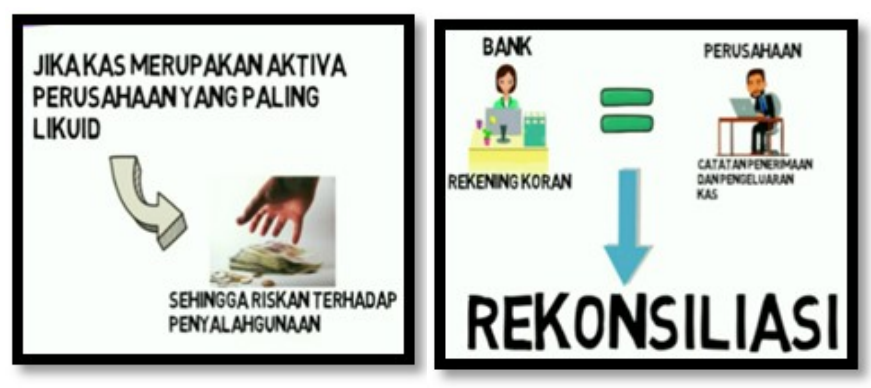

Gambar 5 Bagian Pendahuluan Media Komik Digital Akuntansi

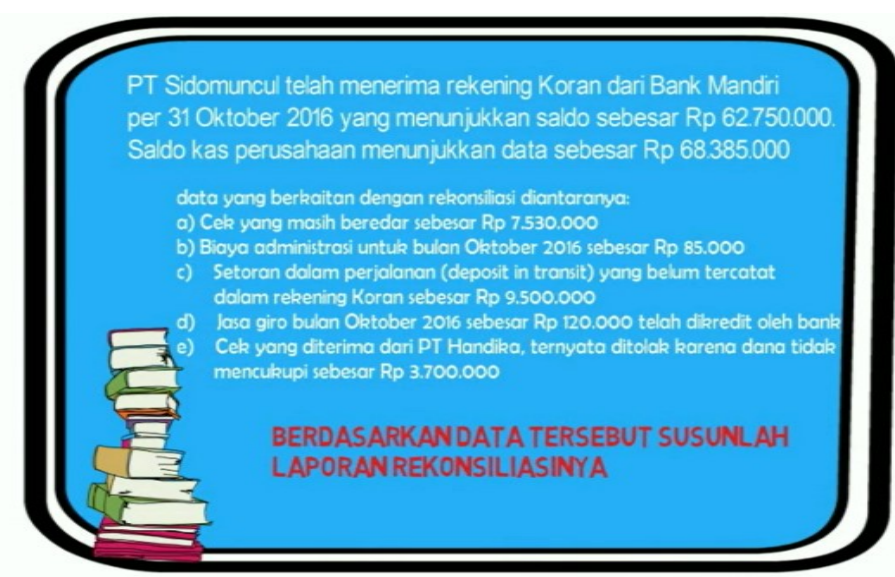

Gambar 6 Bagian Latihan dalam Media Komik Digital Akuntansi 


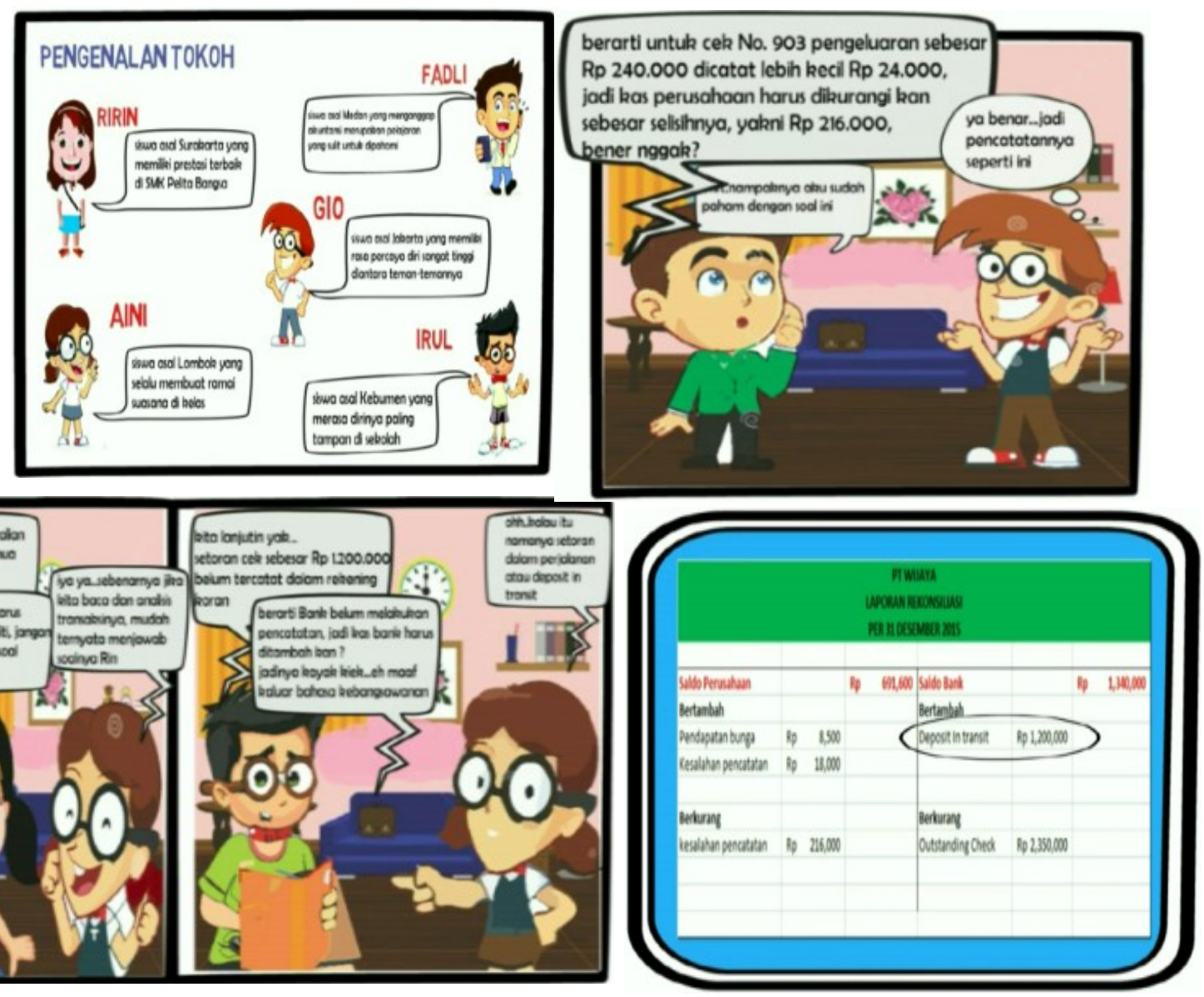

Gambar 7 Bagian Cerita Komik Dalam Media Komik Digital Akuntansi

\section{Validasi Desain Produk}

Draft produk awal media pembelajaran komik digital akuntansi yang telah dihasilkan selanjutnya dilakukan penilaian terhadap kelayakan produk yang dihasilkan. Penilaian kelayakan media pembelajaran komik digital akuntansi dilakukan dengan penilaian oleh tim ahli (expert judgement) yang terdiri dari ahli media, ahli materi, ahli bahasa, dan praktisi (guru akuntansi di sekolah). Berbagai saran dan masukan yang diberikan oleh tim ahli dijadikan dasar dalam melakukan perbaikan dan revisi untuk menyempurnakan media komik digital akuntansi yang dihasilkan. Hasil validasi oleh tim ahli yang telah dilakukan, diantaranya:

\section{Validasi Ahli Media}

Aspek media yang dinilai meliputi isi/materi yang disajikan dalam media komik digital, penyajian/ tampilan media, dan pemrograman penggunaan media. Instrumen yang digunakan untuk validasi media yakni angket, dan hasil penilaian kelayakan media pembelajaran komik digital akuntansi oleh ahli media dapat dilihat pada Gambar 8.

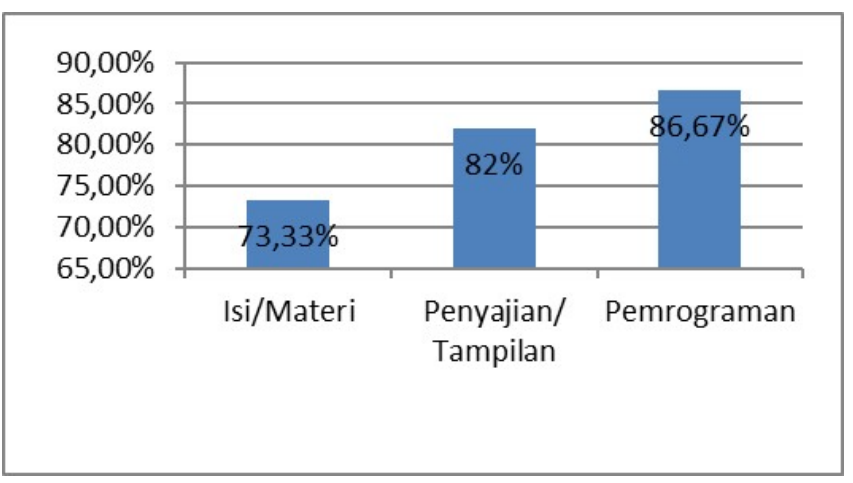

Gambar 8 Hasil Validasi Ahli Media

Berdasarkan hasil validasi ahli media diketahui bahwa aspek isi/materi memperoleh persentase $73,33 \%$, aspek penyajian/tampilan 
sebesar $82 \%$, dan aspek pemrogaman sebesar $86,67 \%$. Sehingga diperoleh persentase ratarata untuk validasi media sebesar $80,67 \%$. Dengan demikian, jika dilihat pada aspek media, media pembelajaran komik digital dapat dikelompokkan dalam kategori sangat baik dan layak untuk diujicobakan serta digunakan dalam proses pembelajaran akuntansi

\section{Validasi Ahli Materi}

Aspek materi yang dinilai mencakup aspek isi/ materi akuntansi yang disajikan dalam komik digital akuntansi dan aspek pembelajaran. Instrumen yang digunakan untuk validasi materi yakni angket, dan hasil penilaian kelayakan media pembelajaran komik digital akuntansi oleh ahli materi dapat dilihat pada Gambar 9.

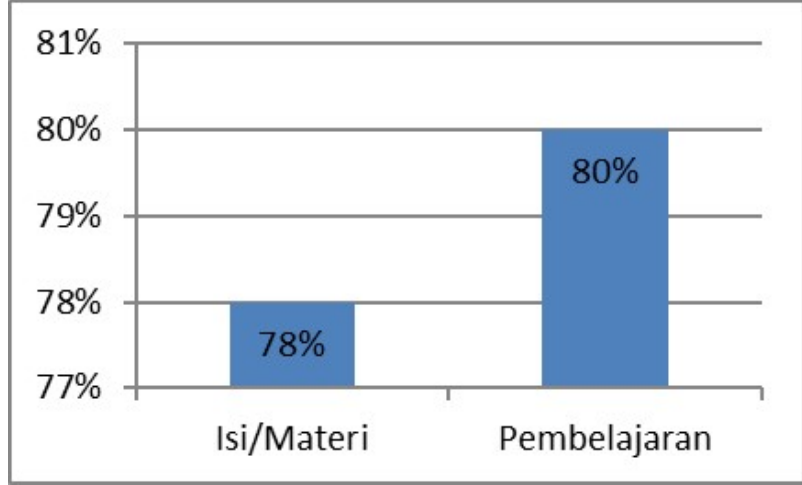

Gambar 9 Hasil Validasi Ahli Materi

Berdasarkan hasil validasi ahli materi diketahui bahwa pada aspek isi/materi mem- peroleh persentase $78 \%$ dan termasuk kategori baik, sedangkan pada aspek pembelajaran memperoleh persentase $80 \%$ dan termasuk kategori baik. Secara keseluruhan pada aspek materi, media pembelajaran komik digital akuntansi memperoleh persentase sebesar 79\%, sehingga media pembelajaran komik digital dapat dikelompokan dalam kategori baik dan layak untuk diujicobakan serta digunakan dalam proses pembelajaran akuntansi.

\section{Validasi Ahli Bahasa}

Aspek bahasa yang dinilai meliputi, aspek lugas, komunikatif, kesesuaian dengan perkembangan peserta didik, dan penggunaan istilah. Instrumen yang digunakan untuk validasi materi yakni angket, dan hasil penilaian kelayakan media pembelajaran komik digital akuntansi oleh ahli bahasa dapat dilihat pada Gambar 10.

Berdasarkan Gambar 10 diketahui bahwa pada aspek bahasa yang meliputi aspek lugas, komunikatif, kesesuaian dengan perkembangan peserta didik, komunikatif dan penggunaan istilah, memperoleh persentase sebesar $100 \%$, sehingga termasuk dalam kategori sangat baik. Media pembelajaran komik digital akuntansi disajikan dengan bahasa yang komunikatif dan mudah dipahami siswa. Oleh karena itu, media pembelajaran komik digital dapat dikatakan layak untuk diujicobakan serta digunakan dalam proses pembelajaran akuntansi.

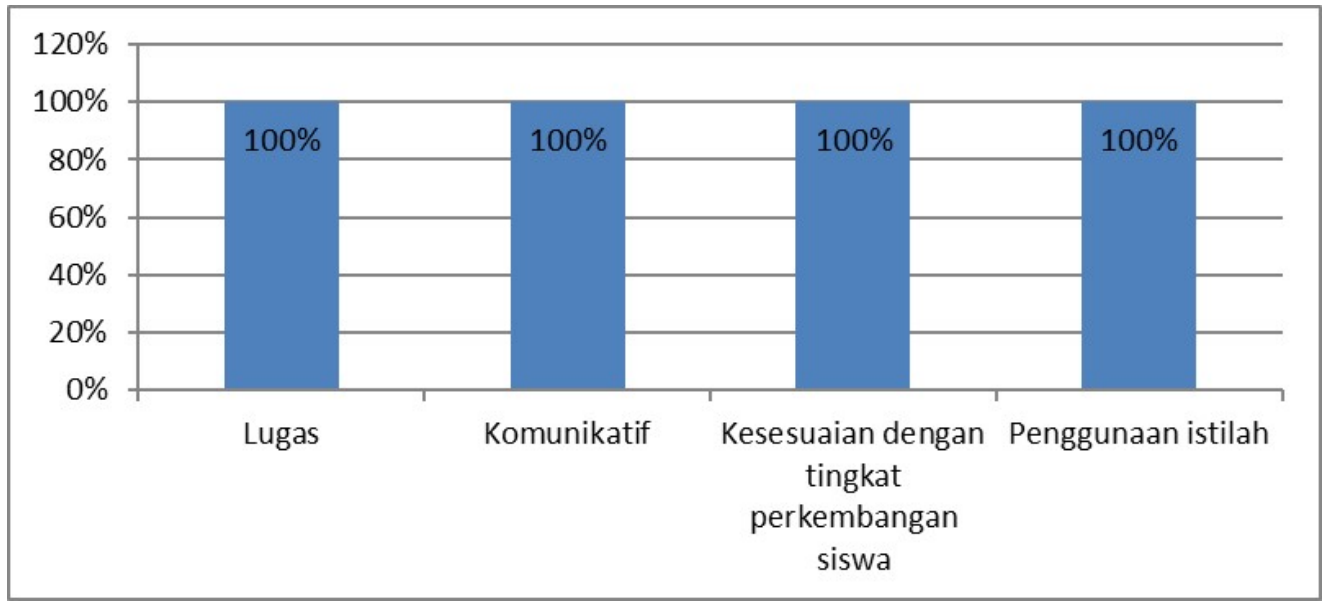

Gambar 10 Hasil Validasi Ahli Bahasa 


\section{Validasi Praktisi}

Validasi praktisi dilakukan oleh guru akuntansi di SMK Muhammadiyah 3 Gemolong untuk menilai kelayakan media pembelajaran komik digital akuntansi. Validasi praktisi meliputi tiga aspek penilaian, yakni aspek isi/materi, penyajian/ tampilan, dan pembelajaran. Hasil penilaian kelayakan media pembelajaran komik digital akuntansi oleh praktisi dapat dilihat pada Gambar 11.

Berdasarkan Gambar 11 diketahui bahwa persentase penilaian kelayakan media dari aspek isi/materi sebesar $79,17 \%$, aspek penyajian/ tampilan sebesar $76,19 \%$, dan aspek pembelajaran $81,33 \%$. Dengan demikian, persentase rata-rata yang diperoleh dari hasil validasi praktisi sebesar $78,89 \%$ dan termasuk dalam kategori baik dan layak untuk digunakan dalam tahapan uji coba dengan beberapa revisi.

Berdasarkan keseluruhan hasil validasi oleh tim ahli (expert judgement) diperoleh persentase rata-rata sebesar $84,64 \%$. Dengan demikian, media pembelajaran komik digital akuntansi ini dikategorikan sangat baik berdasarkan kriteria kelayakan media. Beberapa saran dan masukan yang diberikan praktisi dalam upaya perbaikan dan penyempurnaan media, diantaranya: 1) Perlu adanya jeda tayangan antara materi yang satu dengan yang lain, sehingga ada waktu untuk menganalisis dan memahami materi, karena tingkat kesulitan materi rekonsiliasi bank membutuhkan pemahaman yang lebih; 2) Prolog dalam komik digital terlalu panjang, sehingga ada beberapa narasi yang perlu dikurangi; 3) Perlu ditambahkan rincian tabel rekonsiliasi agar mempermudah siswa memahami dan mengingat materi yang disajikan; 4) Dalam evaluasi atau latihan perlu ditambahkan perintah untuk membuat jurnal koreksi/jurnal penyesuaian.

\section{Uji Coba Terbatas}

Uji coba terbatas dilakukan kepada 10 siswa kelas XI Ak 2 di SMK Muhammadiyah 3 Gemolong untuk menggunakan komik digital dalam proses pembelajaran. Dalam menguji kelayakan media digunakan angket untuk mengetahui respon siswa terhadap penggunaan media komik digital akuntansi. Berdasarkan hasil penilaian angket diketahui bahwa pada aspek media diperoleh penilaian sebesar $83,43 \%$ dengan kriteria sangat baik. Sedangkan pada aspek efektivitas media diperoleh penilaian sebesar $82 \%$ dengan kriteria sangat baik. Secara keseluruhan penilaian yang dilakukan pada uji coba terbatas diperoleh persentase rata-rata sebesar $82,71 \%$ dengan kriteria sangat baik. Oleh karena itu, dapat disimpulkan bahwa penggunaan komik digital akuntansi dalam proses pembelajaran memperoleh tanggapan yang positif dari siswa, dan layak untuk digunakan dalam pembelajaran akuntansi.

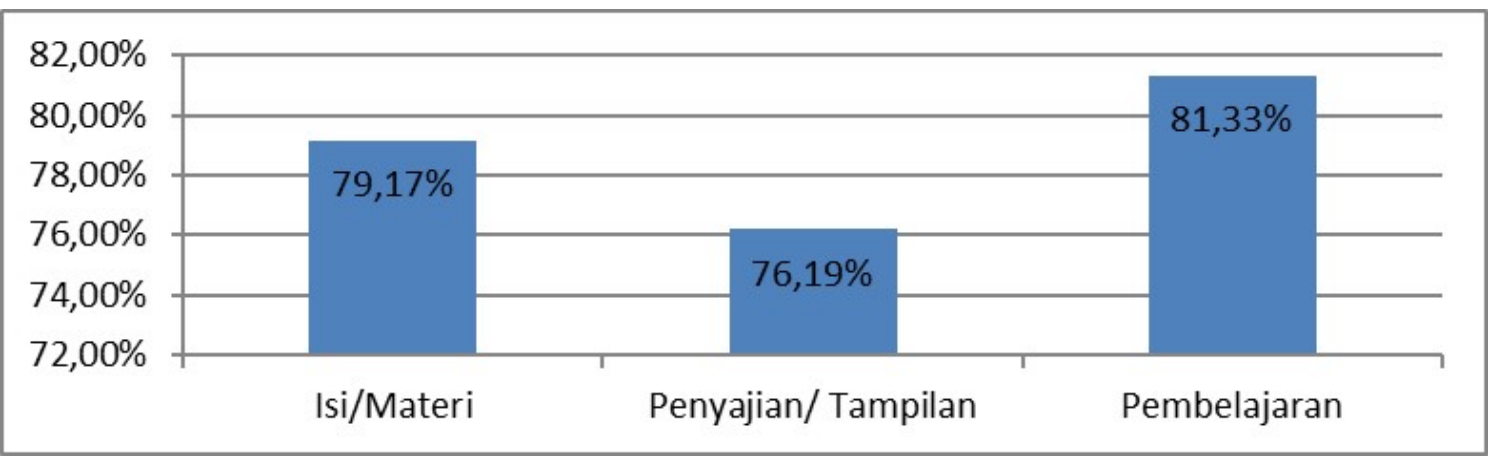

Gambar 11 Hasil Validasi Praktisi 


\section{SIMPULAN DAN SARAN}

\section{Simpulan}

Berdasarkan penelitian yang telah dilakukan diketahui bahwa media komik digital akuntansi yang dikembangkan telah dinyatakan layak untuk digunakan dalam proses pembelajaran sebagaimana hasil penilaian yang dilakukan oleh tim ahli (expert judgement). Hal ini didukung pula oleh data pada hasil uji coba terbatas yang menunjukkan respon positif dari siswa yang menggunakan media komik digital akuntansi. Penggunaan media komik digital meningkatkan antusiasme siswa dalam mengikuti proses pembelajaran, sehingga membuat mereka terlibat aktif, konsentrasi, dan fokus dalam pembelajaran yang berlangsung. Hal inilah yang diperlukan dalam menciptakan kondisi pembelajaran yang mampu mendukung keberhasilan siswa dan ketercapaian pembelajaran.

\section{Saran}

Berdasarkan simpulan, guru diharapkan dapat menggunakan media komik digital akuntansi sebagai salah satu media yang mampu mendukung proses pembelajaran yang lebih menarik, menyenangkan, dan interaktif. Dengan demikian, siswa dapat fokus dan terlibat aktif mengikuti proses pembelajaran yang berlangsung. Siswa dapat belajar dengan memanfaatkan media komik digital yang telah dikembangkan melalui laptop/komputer secara mandiri agar materi akuntansi yang disajikan lebih mudah dipahami. Dukungan kepala sekolah dan stakeholder juga diperlukan untuk mendukung dan memfasilitasi guru melalui berbagai pelatihan dan memberikan sarana pendukung dalam mengimplementasikan media pembelajaran komik digital sebagai upaya peningkatan kualitas pembelajaran. Pengembangan media komik digital masih ditemukan beberapa kelemahan. Oleh karena itu, penelitian selanjutnya diharapkan dapat mengembangkan media komik digital yang tidak hanya disajikan dalam laptop/komputer, namun dapat disajikan dalam bentuk mobile phone maupun android, sehingga lebih praktis dan dapat digunakan dimanapun dan kapanpun.

\section{PUSTAKA ACUAN}

Anitah, S. 2010. Media Pembelajaran. Surakarta: UNS Press.

Azman, F.N., Zaibon, S.B., \& Shiratuddin, N. 2016. Pedagogical Analysis of Comic Authoring Systems for Educational Digital Storytelling. Journal of Theoretical and Applied Information Technology, 89(2),461-469.

Comer, K. 2015. Ilustrating Praxis: Comic Composition, Narrative Rhetoric and Critical Multiliteracies. Composition Studies, 43(1),75-104.

Lamb, A., \& Johnson, L. 2009. Graphic Novels, Digital Comics, and Technology-Enhanced Learning: Part 1. Teacher Librarian, 36(5),70-84.

Negrete, A. 2013. Constructing A Comic to Communicate Scientific Information About Sustainable Development and Natural Resources in Mexico. Procedia Social and Behavioral Sciences, 103, 200-209.

Newby, T.J., Stepich, D.A., Lehman, J.D., Russell, J.D. 2000. Instructional Technology for Teaching and Learning. New Jersey: Prentice Hall.

Rusman, Kurniawan, D., \& Riyana, C. 2012. Pembelajaran Berbasis Teknologi Informasi dan Komunikasi: Mengembangkan Profesionalitas Guru. Jakarta: PT Raja Grafindo Persada.

Smaldino, S.E., Lowther, D.L., \& Russel, J.D. 2008. Instructional Technology and Media For Learning. New Jersey: Pearson Merrill Prentice Hall.

Sugiyono. 2015. Metode Penelitian dan Pengembangan. Bandung: Alfabeta. 
Tatalovic, M. 2009. Comics As Tools For Science Education and Communication: A Brief, Exploratory Study. Journal of Science Communication, 8(4),1-17.

Wankel, L.A. \& Blessinger, P. 2013. Inventive Approaches in Higher Education: An Introduction to Using Multimedia Technologies in Increasing Student Engagement and Retention Using Multimedia Technologies: Video Annotation, Multimedia Applications, Video Conferencing and Transmedia Storytelling. Cutting-edge Technologies in Higher Education, 6F,3-16.

Waskithasari, I.P. \& Setiasih. 2008. Remaja dan Jenis Bacaan Non-Akademis. Anima Indonesia Psychological Journal, 23(2),120-131.

Yang, Y.T.C. \& Wu, W.C.I. 2011. Digital Storytelling For Enhancing Student Academic Achievement, Critical Thinking, and Learning Motivation: A Year-Long Experimental Study. Computers and Education Journal, 59(12),339-352.

Yunus, M., Salehi, H., Tarmizi, A., Idrus, SFS., Balaraman, S.S.A/P. 2010. Using Digital Comics in Teaching ESL Writing. Universiti Kebangsaan Malaysia.

Zheng, L., Yang, J., Cheng, W., \& Huang, R. 2013. Emerging Approaches For Supporting Easy, Engaged and Effective Collaborative Learning. Journal of King Saud University-Computer and Information Sciences, 26, 11-16. 